\title{
ДЕЯКІ АСПЕКТИ КОНТРОЛЮ ЯКОСТІ ОСВІТИ НА КАФЕДРІ МІКРОБІОЛОГІЇ, ВІРУСОЛОГІЇ ТА ІМУНОЛОГІЇ В УМОВАХ ДИСТАНЦІЙНОГО НАВЧАННЯ
}

\author{
L. B. Romanyuk, N. I. Tkachuk \\ I. Horbachevsky Ternopil National Medical University

\section{SOME ASPECTS OF QUALITY CONTROL OF EDUCATION AT THE DEPARTMENT OF MICROBIOLOGY, VIRUSOLOGY AND IMMUNOLOGY IN THE CONDITIONS OF DISTANCE LEARNING}

\begin{abstract}
Анотація. Пандемія, викликана COVID-19 у світі та Україні, обумовила низку змін у системі надання освітніх послуг загалом і в медичній освіті зокрема. Перехід на дистанційну форму навчання в закладах вищої освіти спричинив низку практичних питань, котрі стосуються оцінки якості навчання. Враховуючи те, що запорукою ефективної роботи закладів вищої освіти $€$ системна та ефективна підготовка висококваліфікованих фахівців, контроль знань є невід’ємною частиною цього процесу. Мікробіологія, вірусологія та імунологія відноситься до фундаментальних дисциплін при підготовці студентів медичного факультету, й остаточним методом оцінки знань з даного предмета є тестовий екзамен «Крок 1. Медицина». Але передумовами якісної підготовки майбутніх фахівців є регулярний та багаторівневий контроль їх успішності, що дозволяє виявити недоліки на ранніх стадіях та їх усунути. Аналіз поточної успішності та підсумки складання іспитів, у поєднанні з опрацюванням складання тестів в on-line режимі, дозволяють спрогнозувати результати складання «Крок 1. Медицина» і вчасно вжити заходів щодо тих студентів, котрі мають високі ризики. На кафедрі мікробіології, вірусології та імунології щосеместрово проводиться опрацювання результатів сесії (тестової та усної співбесіди, результатів складання прекроку) і поточної успішності (динаміка здачі практичних навичок, контроль середнього бала по академічних групах, робота з невстигаючими студентами), обговорення ії на методичних нарадах, завдяки чому успішність студентів упродовж останніх кількох років порівняно з іншими предметами з мікробіології, вірусології та імунології знаходиться на стабільному рівні. Такий підхід до контролю якості знань дає змогу більш ретельно підготувати і спланувати щорічні консультації з підготовки до здачі комплексного тестового іспиту та врахувати питання і побажання студентів.
\end{abstract}

Ключові слова: якість освіти; контроль; мікробіологія, вірусологія, імунологія.

Abstract. The pandemic caused by COVID-19 in the world and in Ukraine has caused a number of changes in the system of educational services in general and medical education in particular. The transition to distance learning in higher education has raised a number of practical issues related to the assessment of the quality of educational services. Given that the key to the effective operation of higher education institutions is the training of highly qualified specialists, knowledge control is an integral part of this process. Microbiology, virology and immunology are fundamental disciplines in the preparation of medical students and the final method of assessing knowledge in this subject is a test exam "Krok 1. Medicine". However, the key to effective training of future professionals is a systematic and multi-level monitoring of their success, which allows to identify shortcomings in the early stages and eliminate them. The analysis of the current success and the results of the exams, in combination with the processing of tests on-line, allow us to predict the results of the "Krok 1. Medicine" and take timely action on those students who are at high risk. At the Department of Microbiology, Virology and Immunology, the results of the session (test and oral interview, the results of the pre-step) and current success (dynamics of passing practical skills, control of the average score by academic groups, work with underachieving students) are processed semestery. meetings, so that the success of students over the past few years compared to other subjects in microbiology, virology and immunology is at a stable level. This approach to quality control of knowledge allows you to more carefully prepare and plan annual consultations in preparation for the comprehensive test and take into account the questions and wishes of students.

Key words: education quality; control; microbiology, virology, immunology.

(c) Л. Б. Романюк, Н. І. Ткачук 
Вступ. Економічні, політичні і соціальні зміни, які відбуваються в Україні, зумовлюють необхідність прискорення реформування системи медичної освіти. Забезпечення якісної вищої освіти в Україні $є$ ключовим моментом як у реформуванні, так і подальшому існуванні національного освітнього простору [2]. Поряд із цим, дефіцит висококваліфікованих медичних працівників у нашій країні і в країнах Європи сприяє росту популярності даного фаху, з одного боку, а з іншого - своєчасна та ефективна підготовка та вдосконалення фахових знань забезпечать високу конкурентоспроможність на сучасному ринку праці $[1,6]$. Пандемія, викликана COVID-19 у світі та Україні, обумовила низку змін у системі надання освітніх послуг загалом і в медичній освіті зокрема [3]. Перехід на дистанційну форму навчання в закладах вищої освіти спричинив низку практичних питань, котрі стосуються оцінки якості надання освітніх послуг [4]. Дистанційне навчання - сучасний засіб реалізації процесу навчання, що базується на використанні сучасних інформаційних та телекомунікаційних технологій, що дають змогу навчатися на відстані без особистого контакту між викладачем і студентом. Дистанційне навчання $є$ рівноцінним з очною, вечірньою, заочною та екстернатною формами, що стає можливим завдяки новітнім інформаційним технологіям [5].

Мета статті - провести аналіз ефективності заходів, що проводяться на кафедрі мікробіології, вірусології та імунології і стосуються контролю якості освіти у студентів медичного факультету на різних етапах засвоєння предмета, а саме впродовж навчання на кафедрі, здачі екзаменаційної сесії та успішності за результатами іспиту «Крок 1 ».

Теоретична частина. 3 метою регулярного контролю успішності студентів та планування заходів щодо її підвищення на кафедрі проводяться методичні наради, де обговорюються результати навчання студентів в академічних групах, динаміка здачі матрикулів практичних навичок, кількість невстигаючих студентів та причини, які до цього призвели, при необхідності про ситуацію 3 предмета повідомляються інспектори деканату для вживання своєчасних заходів. Щосеместрово за результатами зимової та літньої сесій проводиться аналіз успішності студентів у плані обговорення як тестової, так і усної частин іспиту. Крім того, після отримання результатів складання іспиту «Крок 1», працівниками кафедр, відповідальними за факультети, проводиться аналіз успішності та, відповідно, планується з урахуванням рекомендацій навчального відділу ряд лекцій-консультацій на кожному факультеті для підготовки студентів до здачі «Крок 1». Перед екзаменаційною сесією студенти всіх факультетів здають «преКрок» за базою кроківських питань, при цьому позитивний результат $є$ допуском до подальшої здачі (80 \% правильних відповідей) іспиту з предмета. У випадку складання студентом «преКроку» на нижчий відсоток йому пропонують кілька спроб для перескладання, що дозволяє більш ретельно підготувати власне тестову частину.

Специфіка практичних занять для студентів медичного факультету полягає в тому, що викладач повинен у стислій формі подати основну базову інформацію по темі, але основою практичного заняття має бути сучасна інформація щодо методів лабораторної діагностики у мікробіології, вірусології та імунології, які зараз використовуються для диференційної діагностики соматичних та інфекційних хвороб в амбулаторних і стаціонарних умовах практичної медицини. Основна увага, згідно 3 кваліфікаційними компетентностями, відводиться інформації, котра стосується інтерпретації результатів досліджень, оцінці змін у серологічних, імунологічних та бактеріологічних показниках і механізмів виникнення певних змін в організмі хворого, підгрунтям для яких $є$ вплив патогенних або умовно-патогенних мікроорганізмів.

Майже всі теми, що розглядаються на практичних заняттях, складаються із таких трьох моментів, як: практична робота, лекція з даної теми або фрагмент лекції (оскільки, як правило, у робочій програмі кількість лекційних годин значно менша, ніж практичних) та самостійна позааудиторна робота студентів (СПРС). Кожен із цих напрямків має відповідне методичне забезпечення: матеріали для підготовки до практичних занять, лекцій, самостійної роботи, методичні рекомендації для студентів до практичних занять та самостійної роботи, конспекти лекцій, мультимедійні презентації для лекцій та практичних занять, відеофільми для кожної теми, що полегшує проведення практичних занять у дистанційному режимі. Структура засвоєння кожної теми з методичної точки зору складається із таких чотирьох компонентів, як: лекції, практичне заняття, СПРС та індивідуальна робота студентів. На нашій кафедрі приділяється достатньо уваги кожному структурному компоненту. Зокрема, індивідуальна робота студентів включає їх участь у роботі кафедрального науко- 
вого гуртка та підготовку проблемних доповідей на студентські конференції. Незважаючи на деякі труднощі, котрі спричиняє дистанційна форма навчання та карантинні заходи в цілому, викладачі нашої кафедри підготували та провели конференцію для студентів II курсу медичного факультету до Дня боротьби з туберкульозом «Медико-соціальні аспекти туберкульозу», що дала змогу студентам більш детально ознайомитись із цією проблемою та викладачам розкрити потенціал деяких студентів у плані подальшої наукової діяльності.

Значна увага на практичних заняттях відводиться індивідуальній роботі студентів, що полягає у підготовці виступів, презентацій та реферативних доповідей на заздалегідь обумовлені з викладачем теми, для прикладу, на темі «Лабораторна діагностика інфекцій, що викликаються рабдо- корона-, рота- та аренавірусами» студентам пропонують підготувати реферативне повідомлення про сучасні вакцини, що використовуються для специфічної профілактики коронавірусної інфекції, на темі «СНІД. Онкогенні віруси» - виступ на тему «Профілактика СНІДу для осіб із груп ризику» тощо. Така форма підготовки до практичного заняття дає змогу поглибити знання для студентів, оскільки вони отримують змогу опрацювати додаткові джерела інформації і поділитись із своїми колегами, при цьому викладач оцінює достовірність та користь поданої інформації, повноту розкриття проблеми та творчий підхід студента до реалізації індивідуального проекту. Також, згідно зі шкалою оцінювання, такі роботи претендують на найвищі бали, що заохочує студентів і з цього боку, та дає можливість покращити свою загальну успішність.

Вирішальна роль у дистанційній підготовці відводиться викладачу, який повинен доступно і водночас на достатньо високому навчально-методичному рівні донести матеріал із дисципліни, котрий стосується морфології, фізіології бактерій і вірусів, методів діагностики інфекційних та неінфекційних патологій, причиною яких є зміни у мікробіоті, засобів специфічної профілактики інфекційних захворювань. Студенти повинні зрозуміти необхідність мікробіологічних знань для їх подальшої практичної діяльності. Для прикладу: проходження працівниками медичних оглядів, зокрема досліджень на носійство бактерій тифодизентерійної групи та золотистого стафілокока, кратність дослідження чистоти повітря у пологових залах, маніпуляційних та операційних приміщеннях, що входить у програму нашого предмета.
На перший план підготовки фахівців такого рівня виходить аналітична складова, а саме зробити правильні висновки та розробити алгоритм дій у тій чи іншій ситуації, спираючись на наявну об’ єктивну інформацію.

Для того щоб об’єктивніше оцінити якість викладання, застосування нових методик, структурований підхід до подання інформації, на кафедрі регулярно проводиться анкетування студентів II та III курсів. Під час анкетування респондентам пропонують відповісти на запитання, що стосувались повноти і якості методичного забезпечення нашої дисципліни, організації навчального процесу на кафедрі, об’єктивності оцінювання знань і практичних навичок, наявності можливості для реалізації творчого потенціалу студентів у процесі вивчення мікробіології, вірусології та імунології, дають можливість висловити свої конкретні пропозиції щодо вдосконалення проведення практичних занять та лекцій. Такий метод аналізу навчального процесу дає змогу підтримувати постійний зворотний зв'язок із студентською аудиторією та своєчасно реагувати на зміни атмосфери у студентському середовищі.

Дистанційна форма організації проведення практичних занять відповідає попередньо затвердженому плану, й оцінювання знань студентів на кожному занятті включає такі ланки:

- вхідний рівень знань студентів (що перевіряється на початку заняття шляхом обговорення особливостей проведення певних практичних робіт, демонстрації викладачем слайдів та відеофільмів, мікрофотографій, схем діагностики);

- участь в усній співбесіді (або заслуховування реферативних повідомлень, презентацій по темі заняття, вирішення ситуаційних задач, обговорення тестів з бази «Крок 1» тощо);

- підсумковий контроль знань (проводиться, як правило, у вигляді on-line вирішення тестів у системі Moodle).

Комплексна оцінка за кожне практичне заняття включає всі вказані компоненти, однак кожен вид діяльності має свої критерії оцінювання.

Регулярно, впродовж навчального року на методичних нарадах кафедри розглядається стан успішності студентів, динаміка здачі матрикулів та відпрацювання пропущених занять і негативних оцінок.

За результатами останньої сесії студентів медичного факультету був проведений порівняльний аналіз поточної успішності та результатів усної 
співбесіди, і проаналізовано результати порівняно з минулим роком для оцінки впливу дистанційної форми навчання на підсумкові результати засвоєння мікробіології, вірусології та імунології.

Для прикладу, був проведений порівняльний аналіз здачі усної співбесіди у рамках комплексного іспиту $з$ дисципліни на медичному факультеті за 2019-2020 та 2018-2019 н. р. (табл. 1).

Таблиця 1. Порівняльний аналіз здачі усної співбесіди у рамках комплексного іспиту з дисципліни на медичному факультеті за 2019-2020 та 2018-2019 н. р.

\begin{tabular}{|l|c|c|}
\hline \multirow{2}{*}{$\begin{array}{c}\text { Кількість балів, } \\
\text { отриманих за }\end{array}$} & \multicolumn{2}{|c|}{ Кількість студентів (\%) } \\
\cline { 2 - 3 } усну співбесіду & $2018-2019$ н. p. & $2019-2020$ н. p. \\
\hline Не склали & $20(6,09 \%)$ & $22(7,03 \%)$ \\
\hline 13 & $55(16,76 \%)$ & $46(14,67 \%)$ \\
\hline 14 & $80(24,39 \%)$ & $40(12,78 \%)$ \\
\hline 15 & $67(20,43 \%)$ & $57(18,25 \%)$ \\
\hline 16 & $48(14,63 \%)$ & $50(15,97 \%)$ \\
\hline 18 & $24(7,33 \%)$ & $54(17,25 \%)$ \\
\hline 20 & $34(10,37 \%)$ & $44(14,05 \%)$ \\
\hline Всього & 328 & 313 \\
\hline
\end{tabular}

Такий аналіз дав змогу порівняти успішність студентів, які перебували на стаціонарному та дистанційному навчанні, і результати свідчать про збільшення кращих оцінок у 2019-2020 році під час зимової сесії, яка проходила в дистанційному режимі, при тому, що кількість тих, хто не склав, була практично однаковою. На покращення успішності могли повпливати, по-перше: домашні умови, у яких студенти складали співбесіду дистанційно, та відсутність стресу; по-друге, кількість тих, хто склали іспит на посередні оцінки, значно зменшилася

\section{Список літератури}

1. Мотивація навчальної діяльності як запорука успішної професійної підготовки студента / Н. П. Коваленко, С.В.Пономаренко, Г. Д. Поспєлова, О. Л. Шерстюк // Сучасний підхід до викладання навчальних дисциплін в контексті підвищення якості вищої освіти : матеріали 50-ї наук.-метод. конф. викладачів і аспірантів (Полтава, ПДАА, 26-27 лют. 2019 р.). - Полтава, 2019. - С. 13-16.

2. Особливості функціонування системи внутрішнього забезпечення якості вищої освіти в Тернопільському національному медичному університеті імені І. Я. Горбачевського МОЗ України / М. М. Корда, А. В. Чорномидз, А. Г. Шульгай, А. І. Машталір // Медична освіта. - 2020. - № 4. - С. 32-37. https://doi.org/10.11603/ me.2414-5998.2020.4.11655. при дистанційній формі, що свідчить про те, що студенти більш ретельно готувалися до іспиту.

Аналіз результатів складання комплексного іспиту «Крок 1» порівняно з 2019 р. (табл. 2), навпаки, виявив зниження успішності його складання, що може бути пов'язано із відсутністю у весняному семестрі ректорських контрольних робіт, котрі включали тести бази «Крок 1», та відповідних предметних консультацій, які проводилися щорічно із студентами перед складанням комплексного іспиту.

Таблиця 2. Аналіз результатів складання комплексного іспиту «Крок 1» за 2019 та 2020 роки

\begin{tabular}{|l|c|c|c|}
\hline $\begin{array}{c}\text { Рік } \\
\text { проведення }\end{array}$ & $\begin{array}{c}\text { Сукупний \% } \\
\text { успішності } \\
\text { за тест }\end{array}$ & $\begin{array}{c}\text { Субтест 3 } \\
\text { мікробіології, } \\
\%\end{array}$ & $\begin{array}{c}\text { Загальне місце } \\
\text { у рейтингу } \\
\text { дисциплін }\end{array}$ \\
\hline 2019 & 72,0 & 72,7 & $4-5$ \\
\hline 2020 & 67,7 & 69,4 & 4 \\
\hline
\end{tabular}

Висновки та перспективи подальших досліджень. Таким чином, системний підхід до аналізу успішності на рівні кафедри та врахування результатів незалежного оцінювання за допомогою іспиту «Крок 1» дають змогу більш ретельно підходити до контролю знань студентів та ефективніше планувати заходи щодо її покращення, зокрема визначитись із кількістю предметних консультацій та їх змістом і наповненням, скласти графік відпрацювань із врахуванням потреб на певному етапі навчання та раціонально організувати здачу практичних навичок студентами II-III курсів медичного факультету.

У майбутньому працівники нашої кафедри планують провести анкетування студентів з питань покращення контролю якості освіти на всіх вказаних рівнях та завдяки такому зворотному зв’язку із студентами покращити їх успішність.

3. Про запобігання поширенню на території України коронавірусу COVID-19 : Постанова Кабінету Міністрів України від 11 берез. 2020 р. № 211.

4. Про затвердження Положення про дистанційне навчання : наказ Міністерства освіти і науки України від 25 квіт. 2013 р. № 466.

5. Рафальська О. О. Технологія змішаного навчання як інновація дистанційної освіти / О. О. Рафальська // Комп’ютерно-інтегровані технології: освіта, наука, виробництво. - 2013. - № 11. - С. 11.

6. Саидмуратова У. Р. Тестирование как метод контроля и мониторинга знаний при обучении иностранным языкам в дистанционном образовании / У. Р. Саидмуратова // Молодой ученый. - 2019. - № 19 (257). C. $368-370$. 


\section{References}

1. Kovalenko, N.P., Ponomarenko, S.V., Pospielova, H.D., \& Sherstiuk, O.L. (2019). Motyvatsiia navchalnoi diialnosti yak zaporuka uspishnoi profesiinoi pidhotovky studenta [Motivation of educational activity as a pledge of successful student professional training]. Suchasnyi pidkhid do vykladannia navchalnykh dystsyplin $v$ konteksti pidvyshchennia yakosti vyshchoi osvity: materialy 50-i nauk.-metod. konf. vykladachiv i aspirantiv - Modern Approach to Teaching Disciplines in the Context of Improving the Quality of Higher Education: Proceedings of 50-scientic Method. Conf. Teachers and Postgraduate Students. Poltava: PGAA [in Ukrainian].

2. Korda, M.M., Chornomydz, A.V., Shulhai, A.H., \& Mashtalir, A.I. (2020). Osoblyvosti funkcionuvannia systemu vnutrishnyoho zabezpechenia yakosti vushchoi osvity v Ternopilskomu nacionalnomu meduchnomu universuteti im. I. Ya. Horbachevskoho MOZ Ukrainy [Features of functioning of the system of internal quality assurance of higher education at I. Horbachevsky Ternopil National Medical University of Ministry of Health of Ukraine]. Medychna osvita - Medical Education 4, 32-37. https://doi. org/10.11603/me.2414-5998.2020.4.11655 [in Ukrainian].
3. Postanova Kabinetu Ministriv Pro zapobihannia poshyrenniu na terytorii Ukrainy koronavirusu COVID-19 vid 11 bereznia 2020 r. № 211 [Resolution of the Cabinet of Ministers of Ukraine On prevention of the spread of COVID-19 coronavirus on the territory of Ukraine dated 11.03.2020 No. 211] [in Ukrainian].

4. Nakaz Ministerstva osvity i nauky Ukrainy Pro zatverdzhennia Polozhennia pro dystantsiine navchannia vid 25.04.2013 r. № 466 [Order of the Ministry of Education and Science of Ukraine On approval of the Regulations on distance learning dated 25.04.2013 No. 466] [in Ukrainian].

5. Rafalska, O.O. (2013). Tekhnolohiia zmishanoho navchannia yak innovatsiia dystantsiinoi osviti [Blended learning technology as a distance learning innovation]. Kompiuterno-intehrovani tekhnolohii: osvita, nauka, vyrobnytstvo - Computer-Integrated Technologies: education, science, production, 11, 11 [in Ukrainian].

6. Saidmuratova, U.R. (2019). Testirovanie kak metod kontrolya i monitoringa znaniy pri obuchenii inostrannym yazykam v distantsionnom obrazovanii [Testing as a method of control and monitoring knowledge in teaching foreign languages in distance education]. Molodoy uchenyy - Young Scientist, 19 (257), 368-370 [in Russian]. 